\title{
The Effect of Decision Making, Accounting Activities, Evaluation in Mental Accounting A Culture of Ompangan From Marriage
}

\author{
Joni Hendra ${ }^{1}$, Judi Suharsono ${ }^{2}$, Uswatun Hasanah ${ }^{3}$ \\ 1. State University Panca Marga on Probolinggo. Address: Perumahan Citarum Indah II/37, Kanigaran District, \\ Probolinggo, East Java Province, Indonesia \\ 2. State University Panca Marga on Probolinggo. Address: Probolinggo, East Java Province, Indonesia \\ 3. State University Panca Marga on Probolinggo. Address: Probolinggo, East Java Province, Indonesia \\ *E-mail of the corresponding author: jonihendra@upm.ac.id
}

\begin{abstract}
This study was conducted aiming to determine the effect of mental accounting which consists of decision making, accounting activities, and evaluation of the culture of ompangan. The culture of ompangan is the term "pun" that is spontaneously expressed by those who accept it. The comments were actually donations or donations given to people who were known to be good or close. according to Tago (2016: 112) "buwuh is the local term for a name for the tradition of helping relatives, neighbors, and / or friends who are on a whim

The results of this study indicate that the results of the simultaneous test show that there is a significant influence between decision making, accounting activities, and evaluation affecting the culture of the team, the results of the partial test analysis indicate that decision making has no significant effect on the culture of the group. While accounting activities have a positive and significant effect on the dance culture of marriage. Evaluation has a negative and significant effect on the dance culture of marriage. And from the results of the standardized coefficients test shows that accounting activity is the most influential variable and can be used as one of the considerations for the compiler or giver and the new recipient in the donation (buwuh /ompangan) in the culture of ompangan from the marriage.
\end{abstract}

Keywords: Accounting Activities, Ompangan Culture, Evaluation, Mental Accounting, Decision Making DOI: $10.7176 / \mathrm{EJBM} / 12-6-15$

Publication date: February $29^{\text {th }} 2020$

\section{Introduction}

Accounting is a real science, synonymous with a routine that is close to numbers and various things that are certain, but accounting is also related to various individuals, communities, and organizations. Every individual, group, society, and even organization has their own characteristics and interests. Wirajaya and Gde (2012) in Anggraini (2017: 58) said that "Most accounting studies only discuss technical and clerical aspects which causes knowledge about the social and organizational role of accounting to be low to be applied to the actual environment. Developments made by researchers in their research are able to raise the reality and phenomena that actually occur, both related to the diversity of customs, ethnicity, culture, and religion ".

According to Bintarto and Daldjoeni in Sadilah, et al (2015: 1) cultural diversity is a form of human adaptation or adaptation to their environment, both the physical environment and the socio-cultural environment. One example in Kalibuntu Village, Kraksaan Subdistrict, Probolinggo Regency, East Java has a culture that has taken root from the days of our ancestors. That culture is known as "Ompangan" culture. Ompangan is a culture of mutual contribution of money, goods, or services in the implementation of various events in the Kalibuntu community, especially in marriages. For the Kalibuntu community, the ompangan culture of marriage is an activity whose implementation knows no boundaries, meaning that helping each other is done from family, relatives, 
neighbors, and the surrounding community. They have the awareness or sensitivity to help even though there is an invitation, it is only a good intention to respect each other. The Kalibuntu people consider ompangan culture as a means to strengthen friendship.

In the culture of tompangan, there are also other aspects of giving a compliment or returning a compliment that is mental accounting. Mental accounting is a cognitive process in which individuals record, summarize, analyze, and report financial transactions or events to track the flow of money and control spending. In mental accounting, the components involved include framing effects, specific accounts, self control, decision making, self reports, and hedonic treadmills (Thaler in Rospitadewi and Efferin, 2017: 19).

The formulation of the problems in this study are: 1) is there a simultaneous influence of decision making, accounting activities, evaluation of mental accounting on the culture of the marriage of marriage, 2) is there a partial effect of decision making, accounting activities, evaluation of mental accounting on the culture of marriage from the marriage , 3) where is the more dominant influence between decision making, accounting activities, evaluation in mental accounting on the dance culture of marriage

\section{LITERATURE REVIEW}

\section{Decision-making}

According to Setiadi (2008: 17) "Taking is a process of selecting the best alternative from a number of alternatives systematically to be followed up (used) as a way of solving problems". It can be interpreted that decision making is choosing and determining an alternative which is considered the most appropriate of the several alternatives formulated. The decision must be flexible, analytical and possible to be implemented with the encouragement of infrastructure and available resources (human and material).

\section{Behavioral accounting}

In the practice of accounting, human behavior is the potential and capacity expressed through physical, mental and social activities that occur during his lifetime. In psychology, humans will experience changes in cognitive ways (ways of thinking and gaining knowledge through the activities of remembering, analyzing, understanding, assessing, reasoning, imagining, and understanding through language and subsequently how to use

their knowledge), emotions, capacities and functions of behavior (Bornstein, Kagan and Lerner in Sawarjuwono, 2012: 4).

\section{Behavioral aspects}

\section{Attitude}

According to Thahir (2014: 85) Attitude is the regularity of one's feelings and thoughts and the tendency towards aspects of the environment, reflected in the tendency of behavior in dealing with an environmental situation associated with it, responses that contain cognitive components (knowledge), affective (how far its assessment of objects) and konactive (tendency to act), which is carried out by someone of an object or stimulus from their environment. He showed the direction, potential and drive towards something. 


\section{Motivation}

The word motivation (motivation) is basically the word motive (motive) which means encouragement, cause or reason for someone to do something. Thus motivation means a condition that encourages or becomes the cause of someone doing an action / activity that takes place consciously. (Thahir, 2014: 92).

\section{Perception}

Kast and James in Tahir (2014: 55), "Perception is to understand behavior, because it is a tool by which stimuli (stimuli) affect someone or something organism. A stimulation that is not felt, will not affect behavior.

\section{Emotions}

Emotion (Emotion) is an intense feeling that is directed at someone or something. Emotions have a tendency to impact one's behavior on risk perceptions and risk attitudes in decision making, with regard to goodmood and badmood (Sastri, 2016: 1-2). Good emotional condition (good mood) includes joy, attention or empathy, while bad (bad mood) includes dislike, fear, and disgust.

\section{Evaluation}

According to Arifin (2012: 8), evaluation is a systematic and ongoing process to determine the quality (value and meaning) of something, based on certain considerations and criteria for making decisions.

\section{Mental Accounting}

Mental accounting is a cognitive process in which individuals record, summarize, analyze, and report financial transactions or events to track the flow of money and control spending. In mental accounting, the components involved include framing effects, specific accounts, self control, decision making, self reports, and hedonic treadmills. Humans consider spending as an experience to be evaluated (Thaler in Rospitadewi and Efferin, 2017: 19).

\section{Ompangan Culture From Marriage}

The culture of ompangan is the term "pun" that is spontaneously expressed by those who accept it. The comments were actually donations or donations given to people who were known to be good or close. according to Tago (2016: 112) "buwuh is the local term for a name for the tradition of helping relatives, neighbors and / or friends who are having a desire. These degrees can be in the form of tingkeb for mothers who are seven months pregnant, selapanan for babies aged 35 days, circumcision, mantenan (marriage), khaul or alms for the anniversary of death, or meeting breeds involving family members near or far from one offspring great grandfather. One form of involvement is donations that come in the form of labor, goods, and money. The basic form of this assistance is two kilograms of rice or sugar. Sometimes added with egg noodles, long beans, or other forms of vegetables.

\section{Research Methods}

This type of research uses associative research (relationships) with quantitative data analysis techniques. Associative research is trying to see the relationship between several variables that can explain the hypothesis to 
be tested (Sugiyono in hestungkorowati, 2014: 125). Therefore this study aims to determine the effect of decision making, accounting activities, evaluations in mental accounting on the dance culture of marriage.

In this study, the population used was the hamlet of Sambilangan 1 in the village of Kalibuntu Kec. Kraksaan Probolinggo Regency numbered 115 people, there were 8 RT. The sample in this study uses the purpose sampling method, which is random sampling based on certain specific characteristics or traits. The criteria in this study include: a) respondents (male / female) who have done the writing, b) respondents (male / female) who are married.

So that the sampling in this study as many as 64 people or as many as 8 families from 8 RT, which is based on family understanding. The family understanding referred to is husband or wife.

Based on the data source, the type of data used is primary data, where the required information is obtained by distributing questionnaires to the Kalibuntu community, especially in Sambilangan Hamlet 1. Data collection methods in this study are: Questionnaire, Observation, Library Research, and Documentation.

In accordance with the symptoms faced, then the measurement tool used is the Likert scale. According to Sugiyono (2009: 107) to measure the attitudes, opinions, and perceptions of a person or group of people about social phenomena using a Likert scale.

\section{Results and Discussion}

\subsection{Result of Path Analysis}

Table: 1, Respondent of gender

\begin{tabular}{cccc}
\hline No & Gender & Responden & Prosentase (\%) \\
\hline 1 & Man & 19 & 30 \\
2 & Woman & 45 & 70 \\
\hline & Amount & 64 & 100 \\
\hline
\end{tabular}

Source: Primary data is processed in 2018

Based on the table 1 above it can be seen that of 64 respondents, 19 respondents were male and 45 respondents were female. So that the highest number of samples is 45 female respondents.

Table: 2, Respondent of Age

\begin{tabular}{cccc}
\hline No & Age & Responden & Prosentase (\%) \\
\hline 1 & 20 s/d 30 & 15 & 24 \\
2 & 31 s/d 40 & 20 & 31 \\
3 & 41 s/d 50 & 18 & 28 \\
4 & Diatas 50 & 11 & 17 \\
\hline & Jumlah & 64 & 100 \\
\hline
\end{tabular}

Source: Primary data is processed in 2018 
Based on the table 2 above it can be seen that of 64 respondents, 15 respondents aged 20 to 30 years, 20 respondents aged 31 to 40 years, 18 respondents aged 41 to 50 years, and 11 respondents aged over 50 years. So that the highest number of samples is 20 respondents aged 31 to 40 years.

Table: 3, Respondent of Profesion

\begin{tabular}{cccc}
\hline No & Profesion & Responden & Prosentase (\%) \\
\hline 1 & House Wife & 15 & 24 \\
2 & Trader & 20 & 31 \\
3 & Fisherman & 18 & 28 \\
& Entrepreuner & & 17 \\
\hline & Others & 11 & 100 \\
\hline
\end{tabular}

Source: Primary data is processed in 2018

Based on the above table it can be seen that of 64 respondents, 22 respondents were housewives, 12 respondents worked as traders, 25 respondents worked as fishermen, 3 respondents worked as entrepreneurs, and 2 respondents worked odd jobs. So that the highest sample size is 25 respondents working as fishermen with a percentage of $39 \%$.

\section{Multiple Regression Analysis}

Based on the table 3 above the results of data processing on decision making, accounting activities, and evaluations of the culture of the team in the Kalibuntu community, the Kraksaan sub-district of Probolinggo District, the regression results are obtained as follows:

Table 4. Path Analysis - Result t test

Coefficients ${ }^{\mathrm{a}}$

\begin{tabular}{|c|c|c|c|c|c|c|}
\hline \multirow{2}{*}{\multicolumn{2}{|c|}{ Model }} & \multicolumn{2}{|c|}{ Unstandardized Coefficients } & \multirow{2}{*}{$\begin{array}{c}\begin{array}{c}\text { Standardized } \\
\text { Coefficients }\end{array} \\
\text { Beta }\end{array}$} & \multirow[b]{2}{*}{$\mathrm{T}$} & \multirow[b]{2}{*}{ Sig. } \\
\hline & & B & Std. Error & & & \\
\hline \multirow[t]{4}{*}{1} & (Constant) & .913 & 2.739 & & .333 & .740 \\
\hline & Decision Marking & .180 & .107 & .121 & 1.691 & .096 \\
\hline & Account Activities & 1.026 & .115 & .635 & 8.893 & .000 \\
\hline & Evaluations & .723 & .103 & .503 & -7.007 & .000 \\
\hline
\end{tabular}

a. Dependent Variable: The culture of ompangan

Model Summary

\begin{tabular}{|l|r|r|r|c|}
\hline Model & \multicolumn{1}{|c|}{$\mathrm{R}$} & R Square & \multicolumn{1}{c|}{$\begin{array}{c}\text { Adjusted R } \\
\text { Square }\end{array}$} & $\begin{array}{c}\text { Std. Error of the } \\
\text { Estimate }\end{array}$ \\
\hline 1 & $.616^{\mathrm{a}}$ & .379 & .376 & 1.537 \\
\hline
\end{tabular}

a. Predictors: (Constant), decision, acccount activity, evaluaitons 
hrough the unstandardized coefficients in the results of data processing as presented in table 4 , the prediction model of decision making variables, accounting activities, and evaluations of the culture of can be formed as follows:

$$
\mathrm{Y}=0,913+0,180 \mathrm{x}_{1}+1,026 \mathrm{x}_{2}-0,723
$$

Based on these prediction equations, the regression coefficients of each independent variable can be interpreted as follows:

$\mathrm{X}_{1}=0.180$ (positive value), meaning that the regression coefficient for the decision making variable ( $\mathrm{X} \rrbracket$

is 0.180 . The positive coefficient indicates that the variable $\varangle \mathrm{X} \rrbracket \_1$ has a positive influence on the Ompangan Culture of Marriage in Kalibuntu Village, Kraksaan District, Probolinggo Regency.

$\mathrm{X}_{2}=1.026$ (positive value), meaning that the regression coefficient for the Accounting Activity variable ( $\square \mathrm{X} \rrbracket$

2) is 1.026 . The positive coefficient indicates that the variable $\llbracket X \rrbracket \_2$ has a positive influence on the Ompangan Culture of Marriage in Kalibuntu Village, Kraksaan District, Probolinggo Regency.

$X_{3}=-0,723$ (negative value), meaning the regression coefficient for the Evaluation variable ( $\square X \rrbracket \_3$ ) of -0.723 .

The negative coefficient indicates that the variable $\llbracket X \rrbracket \_3$ has a negative effect on the Ompangan Culture of Marriage in Kalibuntu Village, Kraksaan District, Probolinggo Regency.

(bernilai negatif),

\subsection{Discussion}

\section{Simultaneous Test (F Test)}

Testing of regression between independent variables decision making, accounting activities, and evaluations of the culture dependent variables at the significant level of 5\%. The number of samples (n) is 64 and the number of independent / independent variables $(\mathrm{k})$ is 3 , so that we can find out the numerator $\mathrm{Dk}=\mathrm{k}=3$ and the denominator $\mathrm{Dk}=\mathrm{N}-\mathrm{k}-1=60$. After the numerator and denominator are determined, then from table $\mathrm{F}$ a value of 2.758 was obtained.

Table 5. Path Analysis - Result F test

ANOVA



a. Dependent Variable: The culture of ompangan

a. Predictors: (Constant), decision, acccount activity, evaluaitons

In table 5 above it can be seen that $F_{\text {_calculate }}=45.402$ and a significant value of $0.000<0.05$, then the independent variables of decision making, accounting activities, and evaluation together (simultaneously) have a significant effect on the culture of computing. Based on these results, the hypothesis stating that free decision making, accounting activities, and evaluations simultaneously affect the culture of partners is proven in this case H_0 is rejected. 
This is in line with research conducted by Elen Rospitadewi and Sujoko Efferin (2017), showing that mental accounting is a core component of the workings of the mind and the accompanying actions that continue to be repeated unnoticed. The repetition consists of several stages, namely the framing effect, the formation of specific accounts, self control, decision making, self report, and finally the hedonic treadmill.

So that it raises the perception of what has utility (usefulness) as a desire that must be fulfilled. This perception gives the illusion of what is considered good to get and what is "not good" to avoid.

Obtaining certain material, relationships, and / or experiences that are considered good are the objects that are attached. Conversely, material, forms of relationships, and / or other experiences that are perceived as not good must be avoided. These three things if considered good will give "happiness".

\section{Partial Test (t test)}

Based on the results of calculations using the SPSS 21 program as shown in Table 4 above, it can be seen the effect of partially independent variables on the dependent variable that $t$ calculated for the decision making variable pengambilan $\left(\mathrm{X} \rrbracket \_1\right)$ is greater than $\llbracket \mathrm{t} \rrbracket$ table that is equal to $1.691>1,670$ and the probability level is $0.096>0.05$ then $\llbracket \mathrm{H} \rrbracket \_0$ is accepted. Which means that the decision-making variable in mental accounting has an effect but is not significant on the culture of $(\mathrm{Y})$. This is the same as the evaluation variable $\square\left(\mathrm{X} \rrbracket \_3\right)$ obtained t-count value of -7.007 and $t$-table equal to 1.670 (based on the $t$ distribution table) with a significance value of $0,000(p<0.05)$. It can be concluded t_count $>t$ _table and the significance value is $0,000<0.05$ then $\varangle \mathrm{H}$ $\searrow \_0$ is accepted. Which means the evaluation variables in mental accounting partially have a negative and significant effect on the culture of $(\mathrm{Y})$.

This is in line with research conducted by Nadia Kartika and Rr. Iramani (2013) which showed no discovery of the influence of emotion on risk perception, but contrary to the results of research conducted by Tri Afrida Rizqi Ameliya (2012), which states that emotion has a significant effect on a person's assessment of risk (risk perception). The reason for the differences in research results can be due to the characteristics of respondents who are dominant at age $>45$ years and who are married. Respondents of this age tend to have a more stable emotional level and with a family status, their first priority is not only for personal interests but for the future needs of the family, so they are expected to get returns that will later be used for families, so they also expected to not be affected by the emotional state.

Similar to the research conducted by Emiliana Sadilah, et al (2015), the results of her research showed that decision making made there was an element of coercion that people had to come to meet during the celebration, but by the community it was a tradition that could not be eliminated and was a form of anticipation when community solidarity began menuru. There is a kind of bad feeling or "pekewuh" if it does not come jagong after being slashed. The more so people who are haunted are relatives or close relatives.

The influence of accounting activity (X $\left.\mathrm{X} \_2\right)$ on the culture of a (Y). Based on the Regression test results obtained t-count value of 8.893 and $t$-table of 1.670 (based on the $t$ distribution table) with a significance value of $0,000(\mathrm{p}<0.05)$. It can be concluded t_count $>\mathrm{t} \_$table and the significance value is $0,000<0.05$ then $\varangle \mathrm{H} \nabla \_0$ is rejected. Which means the accounting activity variable in mental accounting partially has a positive and significant effect on the dance culture of marriage. 
This is in line with research conducted by Made Citra Yuniastuti (2014), the results of his research show that a person's ability to organize, plan and control is related to the bias of accounting mental behavior as said by thaler in kivets that someone who has mental accounting has a systematic mind to adjust expense income. McKay, Atkinson, and Crame in Linda Ariany Mahastanti (2012) who said older people are more likely to see themselves as savers, the majority of parents are very careful about money management and closely monitoring their spending.

\section{Dominant Test}

The dominant independent variable influencing the dependent variable can be known from the t-count value with $\alpha 0.00$ then the t-count value X2 $=8.893$ is greater than the t-count value of X1 and X3 namely 1.691 and 7.007. Which shows that the variable $\mathrm{X} 2$ (accounting activity) is more dominant influence on the variable $\mathrm{Y}$ (Ompangan culture) than the variables X1 (decision making) and X3 (evaluation). Thus the formulation of the third problem (H_3) which was established proved to be "the variable of accounting activity that has a dominant influence on the dance culture of marriage.

\section{Conclusion}

Based on the results of inferential testing and supported by a description of the discussion, it can be concluded that; (1) decision making in mental accounting has a partial but not significant effect on the culture of computing, and accounting activities in mental accounting have a partially positive and significant effect on the culture of compilation, (2) evaluation in mental accounting partially has a strong and significant negative influence on the ompangan culture, this means that the higher the level of evaluation carried out, the greater the coperpetrators involving other people in solving problems faced, (3) each variable between decision making, accounting activities, evaluation in mental accounting simultaneously has a positive and significant effect on the ompangan culture, (4) in this study accounting activities have a dominant effect on the ompangan culture

\section{References}

Anggraini, Rosalina Yuri. 2017. MASUKNYA PARADIGMA INTERPRETIF PADA KAJIAN ILMU AKUNTANSI. JURNAL ANALISA AKUNTANSI DAN PERPAJAKAN, Volume 1 Nomor 1: 56-62 Maret 2017.

Arifin, Zainal. 2012. EVALUASI PEMBELAJARAN, EDISI REVISI, CETAKAN KE-2. Jakarta Pusat: Direktorat Jenderal Pendidikan Islam, Kementerian Agama RI.

Kartika, Nadia. Iramani, Rr. 2013. PENGARUH OVERCONFIDENCE, EXPERIENCE, EMOTION TERHADAP RISK PERCEPTION DAN RISK ATTITUDE PADA INVESTOR PASAR MODAL DI SURABAYA. Journal of Business and Banking Volume 3, No. 2, November 2013, pages 177 - 188

Mahastanti, Linda Ariany. Wiharjo, Katarina Kumalasari. 2012. MENTAL ACCOUNTING DAN VARIABEL DEMOGRAFI: SEBUAH FENOMENA PADA PENGGUNAAN KARTU KREDIT. Kinerja, Volume 16, Nomor 2 Hal. 89-102 Tahun 2012.

Rospitadewi, Elen. Efferin, Sujoko. 2017. MENTAL ACCOUNTING DAN ILUSI KEBAHAGIAAN: MEMAHAMI PIKIRAN DAN IMPLIKASINYA BAGI AKUNTANSI. Jurnal Akuntansi Multiparadigma JAMAL ISSN 2086-7603, e-ISSN 2089-5879, Volume 8 Nomor 1 Halaman 1-227 Malang, April 2017.

Sadilah, Emiliana. dkk. 2015. ETNOGRAFI MASYARAKAT DESA RANDU ALAS KAJIAN BUDAYA SANTETAN $J A G O N G$. Yogyakarta: Balai Pelestarian Nilai Budaya (BPNB)

Sastri, Dita Prawidya. 2016. PENGARUH EMOTION DAN MENTAL ACCOUNTING PADA RISK PERCEPTION DAN RISK ATTITUDE. Skripsi Sekolah Tinggi Ilmu Ekonomi Perbanas Surabaya. 
Sawarjuwono, Tjiptohadi. 2012. ASPEK PERILAKU MANUSIA DALAM DUNIA AKUNTANSI (AKUNTANSI KEPERILAKUAN), CETAKAN KE-1. Surabaya: Airlangga University Press.

Setiadi, Nugroho J. 2008. APLIKASI TEORI EKONOMI DAN PENGAMBILAN KEPUTUSAN MANAJERIAL DALAM DUNIA BISNIS, EDISI PERTAMA, CETAKAN KE-1. Jakarta: Prenada Media Group.

Sugiyono. 2015. METODE PENELITIAN KUANTITATIF, KUALITATIF, DAN R\&D CETAKAN KE-22. Bandung: Alfabeta.

Tago, Mahli Zainuddin. 2016. GURU KEHIDUPAN: CERITA TENTANG AGAMA DAN MASYARAKAT. Yogyakarta: LP3M UMY.

Tahir, Arifin. 2014. BUKU AJAR PERILAKU ORGANISASI, EDISI 1, CETAKAN 1. Yogyakarta: Deepublish. 